\title{
Die rol van die openbare pers in die bevordering en totstandkoming van die kerkvereniging van 1885
}

\author{
SP Pretorius
}

\section{Abstract}

The contribution by the public press in promoting and establishing the merging of the three existing churches in the Zuid-Afrikaansche Republiek in the period 1881-1885.

With this paper it is endeavoured to indicate that the public press, particularly in the years 1881 to 1885 , made an important contribution to the promotion of the merging of the three existing churches in the Zuid-Afrikaansche Republiek in that same period.

The hitherto unknown unity resulting from the developing Afrikaner Nationalism after the First Boer War of 1880 to 1881, has been overemphasized by the press to encourage a sense of emotionality to permit the political unity to overflow into the ecclesiastical province.

\section{INLEIDING}

In hierdie poging om die rol van die openbare pers te probeer peil in die bevordering en totstandkoming van die kerkvereniging van 1885 , is die aandag bepaal by die groter dagblaaie wat in daardie jare verskyn het. Kerkblaaie soos De kerkbode, De Maandbode, Het Kerkblad, De Christen en ander se beriggewing in dié verband is nie in aanmerking geneem nie.

Dat die openbare pers ' $n$ belangrike rol gespeel het in die aanloop en totstandkoming van die kerkvereniging, is nie te betwyfel nie. Tog moet steeds gewaak word om nie die invloed van die pers te oorbeklemtoon nie, aangesien steeds rekening gehou moet word met probleme soos afstande en stadige vervoermiddels wat die verspreiding van koerante bemoeilik en vertraag het in daardie dae.

Opvallend was die geweldige belangstelling van die Kaapse pers in die Transvaalse kerkvereniging. Niénet die groter koerante soos $\mathrm{De} \mathrm{Pa}$ triot en De Zuid-Afrikaan en De Volksvriend nie, maar selfs ook kleinere plaaslike koerante soos De Oudshoorn Courant (De Oudshoorn Courant 
1881-1884), De Colesberger (De Colesberger 1884), De Graaff-Reinetsche Courant (De Graaff-Reinetsche Courant 1884), De Eendracht (De Eendracht 1885-1886), en ander, het voortdurend aandag geskenk aan die saak. Hoe bekombaar die groter Kaapse koerante in Transvaal was, is nie vasstelbaar nie, maar waarskynlik moes dit die Transvalers tog bereik het en mettergaan bygedra het tot die beïnvloeding tot Kerkvereniging.

Die belangstelling van die Kapenaars in die Transvaalse kerksake kan alleen toegeskryf word aan die ontwaking van die nasionale eenheidsgevoel van die Afrikaner na die Eerste Vryheidsoorlog, wat nie net tot Transvaal beperk gebly het nie, maar ook uitgekring het na die ander provinsies sodat tereg van die ontwaking van Afrikanernasionalisme gepraat kan word (Van Jaarsveld 1959 en Kotzé 1969). Teleurstellend is die karige kommentaar van die Transvaalse koerant, De Volkstem, wat meestal net notule-weergawes, sonder rekasionele kommentaar, van die verenigingsonderhandelinge weergegee het (De Volkstem, November 1881).

\section{DIE ROL VAN DIE OPENBARE PERS IN DIE AANLOOP TOT DIE KERKVERENIGING IN DIE TYDPERK 1877-1880}

Die tydperk voor die anneksasie van Transvaal in 1877 is op kerklike gebied in Transvaal grootliks gekenmerk deur onenigheid. Die druk van die anneksasie van Transvaal en die Engelse besetting in die jare $1877-1880$ was 'n belangrike faktor om 'n nuwe samehorigheidsgevoel en nasionale bewussyn by die Transvaalse volk in die besonder, maar ook by al wat Afrikaner was, aan te wakker (Pont 1978: 293).

Terwyl die Transvaalse volk op staatkundige gebied deur die eenheidsgevoel besiel is, wou hulle dit ook kerlik ' $n$ gestalte gee (Botha 1966: 59 en Van der Watt 1980: 85). Dit was reeds merkbaar kort na die anneksasie van Transvaal.

Om eenheid op kerklike terrein te bewerkstellig, moes 'n gesindheidsverandering plaasvind. Kort voor 1877 het onderhandelinge om 'n beter gesindheid tussen die Nederduits Gereformeerde en Nederduitsch Hervormde Kerke in Transvaal te bereik, nog misluk (Keet 1942: 117). Maar reeds vanaf die Sewende Algemene Kerkvergadering van die Nederduits Gereformeerde Kerk van die Zuid-Afrikaansche Republiek in Oktober 1875 te Nazareth, was daar blyke van 'n gesindheidsverandering. By die Algemene Kerkvergadering van díe Kerk in Junie 1877 te Lydenburg (Notule Algemene Kerkvergadering Neder- 
duits Gereformeerde Kerk 1877), word hierdie gesindheidsverandering verder opgemerk wanneer die vergadering na aanleiding van 'n beskrywingspunt van die gemeente Marico (Notule Kerkraadsvergadering Marico 1877: 54 en Notule Algemene Kerkvergadering Nederduits Gereformeerde Kerk 1877), besluit om 'n vorige besluit, in 1873 geneem, te herroep, wat bepaal het dat geen predikant van die Nederduits Gereformeerde Kerk in die Zuid-Afrikaansche Republiek 'n beroep na die Hervormde Kerk mag aanneem nie (Du Toit 1979: 100 en Gerdener 1930: 366).

Hierdie gesindheidsverandering word deur De Zuid-Afrikaan aangegryp om aan die gedagte van kerkvereniging wat oral begin posvat het, prominensie te verleen. Hierdie koerant berig dat daar van verskeie kante stemme begin opgaan dat daar daadwerklik gepoog moet word om die Transvaalse Kerke te verenig. Die gedagte word ook geopper dat 'n konferensie oor die saak gehou moet word:

dat er wel behoefte is aan ene Conferentie, de Leeraars van de drie afdeelingen, waarin de Gereformeerde Kerken ten uwent thans gesplitst zijn, ... zoo gewichtig als de wedervereniging der drie Secties van de kerk wel is, zoo noodzakelijk is het, dat de Broeders eerst nader bij elkander komen om de handen aan het werk te slaan (De Zuid-Afrikaan, Julie 1877).

Gedagtes soos hierdie is voortdurend in die verskillende koerante geopper en dit het 'n groot bydrae gelewer om die eenheidsgedagte op kerklike vlak te stimuleer en te laat groei. Met die uitbreek van die Eerste Vryheidsoorlog in 1880 het die gedagte van kerklike eenwording reeds diep wortel geskiet. Gedagtes ten gunste van 'n kerkvereniging is selfs op die vlak van die Algemene Kerkvergadering uitgespreek.

\section{DIE ROL WAT DIE OPENBARE PERS GESPEEL HET IN DIE BEVORDERING VAN DIE KERKVERENIGINGSGEDAGTE NA DIE VRYHEIDSOORLOG}

$\mathrm{Na}$ die suksesvolle afloop van die oorlog van 1880-1881 was die nasionaal-politieke eenheidsgevoel onder die burgers van Transvaal baie hoog. Die Vryheidsoorlog self het hierdie gevoel geweldig aangewakker. Die gedagte het nóú, meer as boit tevore geleef dat die Zuid-Afrikaansche Republiek, om sy herwonne vryheid te handhaaf, 'n verenigde en eensgesinde kerk nodig gehad het. 
Reeds gedurende die oorlog het die lede van die onderskeie Kerke in Transvaal nader na mekaar beweeg (Notule Algemene Kerkvergadering Nederduitsch Hervormde kerk 1881: 33). Vars in die geheue was die suksesvolle militêre stryd waarin lidmate van al drie Kerke skouer aan skouer geveg het om die verlore vryheid te herwin (Notule Algemene Kerkvergadering Nederduitsch Hervormde Kerk 1881: 34).

De Volkstem vra nou die vraag (De Volkstem, Augustus 1881): 'Waarom sal ons as burgers een wees en nie ook as lede van dieselfde kerk nie?' Die pers het van hier af geen gras onder sy voete laat groei nie en met behulp van hierdie ontwakende nasionale eenheidsgevoel alles in werking gestel om kerklike eenheid te bepleit en te bevorder.

De Volkstem wys daarop dat daar in die oorlog

geen onderscheid tusschen Kerk en Kerk voorkomt niet. Het was één volk bezield door één wensch, geleid door ééne gedachte; Schouder aan schouder bekampte men den gemeenschappelijken vyand. In de kampen deden Leeraren der verschillende Kerken dienst. Te zamen worstelde men aan de sterfbedden, om een hoopvol, jong leven te redden .... Op aarde wandelt een Verzoener rond ... de dood! ... en inderdaad hy bracht tot elkaar, wie zóó ver van elkander en tegenover elkander hadden gestaan in dien ongelukkigen kerkelijken stryd. Alle veeten werden vergeten. Broedermin trok als vroeger in de plaats van Broedermoord. Meer dan een deed een gelofte, dat zoo de Heere, in zijne eeuwige ontferming, het land met den typischen wapenspreuk: 'Eendracht maakt macht' - de onafhanklijkheid hergeven mocht, dat door bloed en tranen gewijde land niet meer het toneel zou zijn van tweedracht, en dat in de eerste plaats Gods Kerk tot eere zou komen ... aldus ontstond in duizenden harten ... de wensch naar kerkelijke vereeniging (De Volkstem, Augustus 1881).

In dieselfde maand rig $D e$ Zuid-Afrikaan'n uitdaging tot die verskillende Transvaalse Sinodes (De Zuid-Afrikaan, Augustus 1881):

Het ware te wenschen, dat een voorstel van vereeniging in de Sijnodes der beide Kerken werd ter sprake gebragt. En dat wel ten eerste. $\mathrm{Nu}$ onder den indruk van den vrijheidsoorlog, waarin men zoo bereidvaardig groote offers bragt in het belang van het algemeene heil, en waarin de godsdienstzin der Transvalers zoo onmiskenbaar bleek, nu zal men onder den magtigen indruk van het groote eenheidsdenkbeeld veel gereeder in het kerkelijke opoffe- 
ringen erlangen van wederzijdsche vooroordeelen en ijdelheden dan men nog kort geleden had of eerlang zal kunnen verkrijgen. Wie is bereid, die poging te doen?

In 'n berig op 26 Augustus 1881 in De Afrikaanse Patriot, van 'n vergadering te Potchefstroom, word hierop geantwoord deur M Wolmarans (De Afrikaanse Patriot, Augustus 1881):

Ik versta dat wij ons in het geestelijke ook moeten vereenigen. De Nederduitsche Hervormde Kerk was de eerste en heeft aanzoek gedaan bij de Nederduits Gereformeerde Kerk om te vereenigen ... dus was onze Kerk toen reeds er voor...

Die pers het veral die eenheidsgevoel wat bereik is op die slagveld gebruik as motivering vir eenheid wat op kerklike vlak moet plaasvind. So sê De Zuid-Afrikaan (Augustus 1881):

En ook op het slagveld scheen alle verschil van sekten en kerken verdwenen te zijn. Het was, of er geen verschil meer van kerkgenootschappen onder elkander bestand. Predikanten van alle drie de kerkgenootschappen wedijverden als het ware met elkander, om hunne eensgezindheid in het belang der goede zaak te betoonen. Een ds Van der Hoff en ds Hendrik Neethling - die nog zoo weinige jaren geleden werden beschouwd als vaandel dragers der scherp tegenover elkander staande Nederduitsch Hervormde en Nederduitsch Gereformeerde Kerken, werkten met gelijke geesdrift om den patriottischen geest der burgers aan te wakkeren, ... én het volk én de leeraren kenden gedurende den krijg slechts ééne zaak, die der vrijheid en onafhankelijkheid. Bezocht een predikant het kamp om het Evangelie te verkondigen, dan dregen de burgers om hen heen, zonder te vragen of hij behoorde tot Van der Hoff, tot Postma of tot Neethling. Het was als of de onafhankelijkheidstryd die de eenheid van het Transvaalsche volk zoo schitterend had te voorschijn geroepen, die alle verschil tusschen de partij van een Kruger, en die van een Joubert of Pretorius had vernietigd, ook de scheidsmuren die de kerken van elkander scheiden, had omvergewerpen, en alle Transvalers inderdaad had gemaakt tot ééne kudde.

Hierby sluit De Patriot van 2 September 1881 aan met die vraag (De Afrikaanse Patriot, September 1881): 
Maar is dit nou wel die tijd om 'n begin te maak met die hereniging? Party seg: Ne, dit sal net meer verdeeldheid en opskudding veroorsaak;

Self dink die blad egter dat dit die beste tyd is daartoe en noem ook die redes:

1. Ons Transvaalse Broeders het in die laaste tije van druk en kommer geleer wat eensgezindheid kan doen en dat eensgezindheid molik is. In die staatkunde was ver langer tyd partye as in die kerk en die partye was nog meer verbitterd teen mekaar as die kerkpartye, so erg dat hulle selfs in burgeroorlog teen mekaar opgetrek en mekaar verjaag het. En nou: Daar was in die laaste tyd nix van te sien nie. Wie kon nou anwys wie vroeger tot die 'Volkslagerparty' behoor het?... Waarom sou die verbroedering oek nie op kerkelik gebied kan plaasvinde nie?

Na die aanwys van nog redes kom die blad tot die slotsom:

1. ' $\mathrm{n}$ Hereniging is wenschlik...

2. 'n Hereniging is uitvoerbaar...

3. 'n Hereniging is nou tydig...

In die pers is ook voortdurend, in aansluiting by die nuutgevonde eenheidsgevoel, gewaarsku teen verdeeldheid. De Zuid-Afrikaan sê in dié verband (Augustus 1881):

En vraagt men naar de reden der bestendiging van die verdeeldheid, dan is het moeijelijk een afdoend antwoord te erlangen. Er was een tijd toen er degelijk grond bestand voor het stichten van eene Nederduitsch Gereformeerde zoowel als van eene Nederduitsch Hervormde Kerk, een tijd toen de beide kerken, indien al niet in hare leerstukken, dan toch in de praktijk min of meer uiteenlopende rigtigen vertegenwoordigden...

Maar nou is die bestaan van drie Hollandse Kerkgenootskappe vir De Patriot' $n$ treurige saak (De Afrikaanse Patriot, September 1881):

Op sig self beschoud sal elkeen al vooraf moet erken, dis treurig dat ons Afrikaners in Transvaal kerkelik in drie partye moet verdeel wees, terwyl hulle origens een op maatskaplik en staatkundige gebied is. En nog treuriger is die verdeeldheid as ons bedenk 
in hoevele opsigte die Kerke één is: één in leer; één in taal; één in eerediens ... Is dit nou nie jammer dat die skeiding ontstaan is en blijf voortbestaan nie? Gewis. En is 'n hereniging nie wenselik nie? Sal eendrag kerkelik ok nie mag maak nie, terwyl verdeeldheid swak maak? Seker.

Hierdie artikel gaan voort in 'n volgende slotuitgawe waarin die volk gewys word op sy plig tot eenheid wat kerksake betref (De Afrikaanse Patriot, Oktober 1881):

Eendrag is altoos 'n eerste vereiste ver elke land en volk. Mar hier nou veral ... 'n Huis of Koninkrijk teen sigself verdeeld kan nie bestaan nie ... Wees eensgesind ... vermijdt alle kerkelijke geschillen ... laat alle onderlinge verdeelheid varen...

Hierdie beriggewing het nie alleen die eenheidsgevoel op die politieke gebied nie, maar ook die gedagte dat daar haas gemaak moet word met kerklike eenwording, telkens laat opvlam.

'n Saak waaraan baie aandag gegee is deur die pers in hierdie tyd, was die beriggewing oor vergaderings wat gehou is ten gunste van kerkvereniging. By hierdie vergaderings was die oogmerk om die kerkvereniging so gou moontlik deur te voer. In 'n volledige berig oor 'n vergadering gehou te Potchefstroom op 30 Julie 1881 word die woorde van E Engelbrecht aangehaal (De Afrikaanse Patriot, Augustus 1881):

Er wordt zooveel in de nieuwsbladen geschreven omtrent eene vereeniging van kerken in onzen Staat; sowel van de Hervormde als Nederduits Gereformeerde gemeenten...

Veral die noodsaaklikheid van kerkvereniging word sterk in die berig op die voorgrond gestel na al die lyding van die Vryheidsoorlog wat politieke eenheid gebring het (De Afrikaanse Patriot, Augustus 1881):

... als de Heer gee't dat wij in de uitvoering er van slagen. $\mathrm{Hij}$ heeft ons op politieke gebied vereenigd. Hoe verschillend waren wij voorheen, in tweedragt, zoowel in.Kerk als in politiek. Wij hebben een korten tyd van lijden en tucht gehad. Moge ... dat die korte tucht ons een goede les was.

Die blad het egter ook in hierdie berig, wat veral die vereniging met haas wil afhandel, tog op twee gevaartekens vir die voorgenome kerkvereniging gewys. Eerstens was dit duidelik dat daar tog mense was 
wat nog nie behoorlik ingelig was nie en vir wie kerkvereniging geen uitgemaakte saak was nie. Dit blyk uit die woorde van J Joubert (in De Patriot, Augustus 1881) van Schoonspruit:

... maar ik wil eerst weten; waarom de vereeniging der kerken hier ter sprake is. Er zijn met mij velen die er mede onbekend zijn...

Die tweede gevaarlig wat betyds geflikker het, maar wat hierna misgekyk is, was die versoek dat gemeentes en kerkrade in die saak van kerkvereniging geken moes word. A Pienaar (in De Patriot, Augustus 1881) se woorde in die verband is betekenisvol:

Wij willen alleen zien of er eene vereeniging kan plaats hebben, wat de gemeenteleden er van denken ... Ik ben voor eene vereeniging ... maar dat moet door de Kerkraden beslist worden.

Uit hierdie en ander berigte het die oproep vanaf De Patriot duidelik weerklink: 'Laat de gemeente zich wendt tot de Algemene Kerkvergadering ... Laat de Kerkraad een aanvang met die zaak maken.'

Ongelukkig is hierdie werkwyse waarin gemeentes en kerkrade geken is, nie gevolg nie (Pont 1955: 135). Van die waarskuwing van De Afrikaanse Patriot het niks tereg gekom nie (September 1881):

Voor de Sijnodes moet die saak nog vereers nie kom nie. Daartoe is dit nog nie rijp nie. En 'n onversigtige besluit in 'n Sijnode geneem kan veel kwaad doen.

Soos bekend het die hele diskussie oor die kerkvereniging buite die gemeentes om gegaan. Selfs pogings van gemeentes om deur midel van memories by die saak betrokke te raak, is telkens van die hand gewys of op die lange baan geskuiwe. Juis omdat gemeentes nie in die saak geken is nie, moes hierdie vereniging uiteindelik misluk.

Die drang tot kerkvereniging wat nie sy oorsprong op kerklike terrein gehad het nie, is verder aangewakker deur die steun wat die politieke leiers, die sogenaamde 'Voormannen des Volks' daaraan verleen het. Hieroor het veral $D e$ Volkstem hom graag uitgelaat in sy beriggewing oor openbare vergaderings wat deur die leiers gehou is om kerkvereniging te bepleit (Pont 1965: 50). Veral die steun wat Kruger, Pretorius en Joubert aan die kerkvereniging gegee het, is voorop behandel (De Volkstem, Desember 1881). Kruger sê in díe verband dat 'iemand van zijne christelijke gezindheid zou afwijken als hij dit voorstel niẹt 
steunde!' Uit die toesprake en oproepe van die volksleiers, soos deur De Volkstem weergegee, was dit duidelik dat die saak van kerkvereniging in die Zuid-Afrikaansche Republiek na die oorlog van 1880-1881 deur hulle bepleit is. Al wat van die kerke verwag was, was om beslag te gee aan die wense wat so eenstemmig deur hulle uitgespreek is.

Wanneer die berigte in die pers, in hierdie tyd voordat met formele onderhandelinge op sinodale vlak begin is, saam geëvalueer word, kan met reg gesê word dat die koerante baie daartoe bygedra het om ' $\mathrm{n}$ klimaat vir kerkvereniging te skep, waar slegs vereniging sonder meer ' $n$ doel geword het, sonder dat die implikasies besef of in ag geneem is. Die beriggewing oor die bydrae vân volksleiers en volksbyeenkomste het meegewerk tot die skep van hierdie klimaat.

\section{DIE ROL WAT DIE OPENBARE PERS GESPEEL HET TYDENS DIE ONDERHANDELINGE TOT KERKVERENIGING}

Die formele onderhandelinge tot kerkvereniging tussen die Nederduits Gereformeerde en Nederduitsch Hervormde Kerk begin op sinodale vlak op Dinsdag, 31 Oktober 1882 wanneer die twee verkose verenigingskommissies mekaar te Pretoria ontmoet (Notule Kommissie van die Algemene Kerkvergadering 1882: 174 en Notule Verenigde Kommissies 1882: 2). Die Gereformeerde Kerk was nie teenwoordig nie. Oor hulle afwesigheid en die redes daarvoor is breed in De Volkstem gehandel (De Volkstem, November 1882). Kortliks word die gevolgtrekking gemaak dat die voorwaardes wat deur die Gereformeerde Kerk gestel is, vir beide die Nederduits Gereformeerde en Nederduitsch Hervormde Kerke onaanneemlik is.

Reeds by die eerste punt van bespreking tussen die verenigingskommissies, naamlik die vasstelling van die leer van die Verenigde Kerk, was dit duidelik dat dié Kerk ' $n$ ander koers as die Hervormde Kerk wou gaan en dat dit juis die struktuur van die Nederduits Gereformeerde kerk wil verteenwoordig. Alhoewel daar in die formulering van leer hewige meningverwisseling ontstaan het (Notule Verenigde Kommissies 1882: 6), berig De Zuid-Afrikaan (November 1882):

De afgevaardigden der Hervormde Kerk boden op dit punt geenen sterken tegenstand en men kwam eindelijk overeen...

Hierdeur word 'n gunstige klimaat vir vereniging geskep, deur voor te gee dat die Hervormde Kerk sonder meer sy beginsels laat vaar. 
In die koerantberiggewing word ook baie aandag verleen aan die standpuntinname van ds HL Neethling van die Nederduits Gereformeerde Kerk (De Zuid-Afrikaan, November 1882). Hy gee voor dat die Belydenis-formule van die Hervormde kerk te los en te vaag was en ook leervryheid aan die hand werk. Hy dring daarom aan op die aanvaarding van die formule van die Nederduits Gereformeerde Kerk. Dié gedagte is vir De Zuid-Afrikaan aanvaarbaar.

By die bespreking van die legitimasie-akte was dit weer De ZuidAfrikaan wat hieroor berig (November 1882):

In de bespreking van dit punt word het duidelijk dat er aan beide kanten bezwaren waren. De Gereformeerden bragten als hun bezwaar uit dat de Acte der Hervormde Kerk niet bindend genoeg en onpassend voor eene Kerk was. Er werd alleen gesproken van verstandelijke bekwaamheid niet van Geloof en Godsvrucht. Die predikant moest enkel een geleerde man zijn en dan was het genoeg. Of hij self bekeerd, wedergebore was, daar voor scheen geene vraag te zijn (volgens de Legitimatie-acte der Hervormde Kerk.) Hij moet toch als leerar anderen leiden tot het kruis van Christus; ... als zondaar andere zondaren den weg wijzen om vergiffenis te krijgen en er werd niet ge-eischt dat hij deze geestelijke bekwaamheid zou bezitten. Verder de legitimatie der Hervormde Kerk bragt ons in verband met die Hervormde Kerk in Holland. De Kerk in Holland was doorgaans liberaal, van daar zou dus het liberalisme onder ons ingevoerd kunnen worden. Van daar komen leerraren die deelen van Gods Woord verwierpen, andere doopformulieren gebruikten. De Legitimatie was dus niet bindend genoeg en paste ook niet voor ene Christelijk Kerk en daarom konden die afgevaardigden die Acte niet aannemen.

Die saak wat hier deur die pers aangesny word, handel oor die colloquium doctum wat in die Kaapse Kerk so 'n belangrike plek ingeneem het. Dit was 'n geleerde gesprek wat met 'n inkomende predikant gevoer word waarin ondersoek gedoen word na sy gevoelens oor wedergeboorte en die persoonlike ondervinding van Gods genade (De ZuidAfrikaan, November 1882). Dit sluit nou aan by die situasie wat in die Nederduits Gereformeerde Kerk ontstaan het sedert 1860 toe die metodisme met sy antroposentriese en arminiaanse basis, in die kerk ingevoer is as teenvoeter vir die liberalisme waarvan die Hervormde Kerk beskuldig is. Hierdie verwysing na die colloquium doctum het die verskil van teologiese standpunt van die twee kerke duidelik na vore ge- 
bring. Teenoor die metodisme waarmee die Hervormde kerk hom nooit vereenselwig het nie, is die Bybels-reformatoriese teologie in die Hervormde Kerk gehandhaaf. Juis daarom was die colloquium doctum nie iets wat die Hervormde kerk van sy aankomende predikante kon eis nie.

Tog is die colloquium doctum aanvaar in die Vereenigde Kerk, met uitsondering van ds Van Warmelo. Daarmee het die Hervormde Kerk sy teologiese basis verlaat en die Bybelse leer van die reformatoriese vadere wat nog altyd ten alle koste verdedig is, prysgegee. Wanneer dit later tot die lidmate van die Hervormde Kerk deurdring, lei dit tot groot ontevredenheid en word dit 'n belangrike rede vir die mislukking van die kerkvereniging. Vir die Verenigde Kerk beteken die aanvaarding van die colloquium doctum dat hy, net soos die Nederduits Gereformeerde Kerk, van die begin af buite die grense van die Bybels-reformatoriese teologie beweeg. Ook in hierdie opsig is die Verenigde Kerk maar net 'n voortsetting van die Nederduits Gereformeerde Kerk met die metodisme as grondslag. Dit wil voorkom of die kommissie van die Nederduits Gereformeerde Kerk met hulle aandrang vir die aanvaarding van die colloquium doctum die basis vir kerkvereniging lê, wat nie 'n vereniging op die oog gehad het nie, maar eerder 'n oorname. In die lê van hierdie basis het hulle die steun van die pers gehad. Met só 'n basis kon kerkvereniging ook nie slaag nie.

By die vasstelling van die ondertekeningsformulier kom dit weer voor asof die pers steun verleen aan die standpunt van die Nederduits Gereformeerde afvaardiging. Alhoewel 'n vergelyking tussen die ondertekeningsformuliere van die twee kerke toon dat dié van die Hervormde Kerk korter en bondiger is en in wese van dieselfde inhoud as dié van die Nederduits Gereformeerde Kerk, word dié van die Nederduits Gereformeerde Kerk aanvaar. Die aandrang van ds HL Neethling om die formulier van die Nederduits Gereformeerke Kerk te behou, geniet ook die steun van De Zuid-Afrikaan (November 1882). Daarenteen word ook verwys na die onverklaarbare berusting van die Hervormde afvaardiging daarby (De Zuid-Afrikaan, November 1882):

De Hervormde Kerkwet bleef toen acter. Ik hoorde niet meer er van spreken; ik merkte niet dat eenig gedeelte of selfs eenig woord er uit overgenoemen werd voor het nieuwe .... Ja, selfs die Commissie uit de Hervormde Kerk sprak niet meer van haar formulier; stelde niet voor om een of ander gedeelte er van te blijven behouden. 
Dit is tog opvallend dat ds Van Warmelo, wat in beginsel beswaar gehad het teen die manier waarop die legitimasie vir die predikante van die Verenigde Kerk vasgestel is, hom tog hier vir 'n vorm van legitimasie gewonne gee, waarteen hy vroeër in sy lewe 'n afwysende houding ingeneem het. Sy toegewing moet waarskynlik daaraan gewyt word dat hy moontlik onder die invloed van die herhaalde oproepe in die pers, die vereniging nie wou verhinder nie, veral aangesien die meerderheid van die vergadering sy gevoelens ten opsigte van die legitimasie nie gedeel het nie. Hy was ook besiel met die eenheidsgedagte soos deur die koerante uitgedra en sou dit bevorder, eerder as om in die weg daarvan te staan. Die invloed van die pers in hierdie opsig mag nie onderskat word nie.

By die bespreking van die Verenigde Kerk se houding ten opsigte van die sendeling, gaan dit vir die Hervormde Kerk om die status van die sendeling. De Zuid-Afrikaan wil hier ook handel oor die begrip 'gelykstelling'. Hy stel dit so (De Zuid-Afrikaan, November 1882):

Onder gelijkstelling dachten de Hervormden iets gansch anders dan de Gereformeerden. Eerstens drukten daarmede uit: Geen onderscheid tusschen predikanten en Zendelingen; Laatsten: Geen onderscheid by lidmaten tusschen gekleurden en blanken. Eersten zeggen dit: Houdt de Zendeling uit het werk en de plaats van den predikant; Laatsten: Laat blanken en gekleurden niet zamen in eene en dezelfde gemeente lidmaten worden.

Dit is die standpunt waaroor die Hervormde kerk dikwels verkwalik is. Met die ophaal van die woord 'gelijkstelling' deur die pers veral, is 'n vurige diskussie aan die gang gesit en waarskynlik was dit die bedoeling dat klarigheid oor die saak verkry moes word by hierdie finale onderhandelinge (Notule Verenigde Kommissies 1882).

Die vasstelling van die name van die Verenigde Kerk was van groot belang vir die Hervormde afvaardiging. Die woord 'Hervormd' was vir vele gemeentelede uitdrukking van alles wat hulle gevoel en gedink het ten opsigte van hulle Kerk in die Republiek en sodoende het die naam ook 'n simbool geword wat sowel intellektuele as emosionele reaksies kon ontlok. Hierdie besondere gehegtheid aan die naam 'Hervormd' kan enersyds daaraan toegeskryf word dat daarmee die onafhanklikheid van die Kaapse Sinode getipeer is en andersyds omdat dié naam vanaf 1865 deur die Nederduits Gereformeerde Kerk onder 'n vraagteken gestel is en dat dit juis ' $n$ aanleiding was om die behoud van die naam op die voorgrond te stel (Pont 1955: 136). Die aanval van ds HL 
Neethling oor die onwettigheid van die naam en dat 'Hervormd' per se staan vir liberaal, het die aandag van veral De Zuid-Afrikaan geniet in sy weergawes. Deurgaans word gevra na bewyse in die beskrywing van hierdie stryd (De Volkstem, 1882-1885). Uit perskommentaar oor die verwerping van die naam Hervormd, blyk dit dat die Nederduits Gereformeerde afvaardiging 'n oorname van die Hervormde Kerk in gedagte gehad het.

Die onderhandelinge tussen die twee verenigingskommissies het twee sake duidelik aan die lig gebring:

Die eerste was dat dit algaande uit die samesprekings duideliker geblyk het dat die basis vir Kerkvereniging wat hier gelê is, nie ' $n$ vereniging op die oog gehad het nie, maar eerder 'n oorname. Dit het veral duidelik geblyk by die vasstelling van die leer, die legitimasie-akte, die ondertekeningsformulier en die vasstelling van die naam van die Verenigde Kerk. Dit wat eie was aan die Hervormde Kerk, die grootste vennoot in die kerkverenigingspoging, moes plek maak vir die formuleringe en opvattinge van die kleinere Nederduits Gereformeerde Kerk. Die Verenigde Kerk moes 'n voortsetting wees van die Nederduits Gereformeerde Kerk en in die proses moes die Hervormde Kerk verdwyn. In die bereiking van hierdie oogmerk het die pers sy aandeel gelewer. Die wyse waarop die werk van die verenigingskommissies telkens rapporteer is, het meegewerk om die standpunt van die Nederduits Gereformeerde Kerk meer aanvaarbaar te maak. Min van die Hervormde standpunt is gerapporteer. Waar dit wel aan die orde kom, is dit dikwels afgemaak as onvolledig (De Zuid-Afrikaan, November 1882 en De Volkstem, Oktober 1882).

'n Tweede opvallende saak was dat nie één van die deelnemende predikante in die hele diskussie die teologiese argumente vir kerkvereniging na vore gebring het nie. Teologies beoordeel was die hele samespreking amateuragtig, ondeurdag en oppervlakkig. Dit wil voorkom of die teologiese argumente teen die agtergrond van die eenheidsdrang deur nie een van die partye as belangrik beoordeel is nie. Ook van die kant van die pers is geen navraag gedoen oor ' $n$ teologiese beoordeling of standpuntinname nie. Dit is eerder doodgesmoor deur die oorbeklemtoning van eendrag en éenheidsgevoel en die voortdurende pleitredes dat vereniging nie in die slag moet bly op grond van meningsverskil nie (De Zuid-Afrikaan, Augustus 1881 en De Afrikaanse Patriot, Augustus 1881, September 1881 en Oktober 1881).

Hierdie beriggewing was in baie opsigte die enigste bron van inligting vir die meeste afgevaardigdes na die onderskeie Algemene Kerk- 
vergaderings wat moes handel oor die werk van die verenigingskommissies, aangesien die gedrukte notules nie so gou beskikbaar was nie. Die invloed wat die pers uitgeoefen het, het baie daartoe bygedra dat die werk van die verenigingskommissies sonder veel wysigings aanvaar is. Die pers het dus ook sy bydrae gelewer tot die oppervlakkige en ondeurdagte besluitneming. Dit is juis op grond van dié beriggewing in De Volkstem, dat ds JC de Vries by die 22ste Algemene Kerkvergadering van die Nederduitsch Hervormde Kerk op 27 November 1882 voorstel (Notule Algemene Kerkvergadering Nederduitsch Hervormde Kerk 1882: 4 en De Volkstem, November 1882):

... dat het werk van de commissie ter vereeniging door deze vergadering goedgekeurd en aangenomen worde bij acclamatie, zonder discussie.

Die beriggewing oor die behandeling van die besluite van die verenigingskommissies deur die verskillende Algemene Kerkvergaderings hierna, was oor die algemeen 'n formele weergawe van die notules van die vergaderings, sonder noemenswaardige kommentaar (De Volkstem, Januarie 1884, April 1884, Mei 1884 en Februarie 1885, De Zuid-Afrikaan, Februarie 1885 en Het Volksblad, Februarie 1885). Oor die algemeen is oproepe gedoen tot versnelde handelinge om kerkvereniging in Transvaal 'n werklikheid te maak. So is daar byvoorbeeld deur De Volkstem breedvoerig aandag gegee aan byeenkomste wat onder andere te Standerton plaasgevind het op 28 Desember 1883; te Piet Retief op 25 Maart 1884 en te Lichtenburg op 28 Maart 1884 waar samesprekings plaasgevind het ter bespoediging van die kerkvereniging (De Volkstem, Januarie 1884, April 1884 en Mei 1884).

Deur middel van die pers is die tafel klaar gedek vir die konstitueringsvergadering van die Verenigde Kerk in Desember 1885. Die notule van hierdie konstitueringsvergadering is volledig deur die pers weergegee (De Volkstem, Desember 1885).

\section{SLOTWOORD}

Die kerkvereniging van 1885 het om verskeie redes misluk waarop nie hier ingegaan word nie. Wanneer daar egter gewys word op die rol van die pers in die totstandkoming van die kerkvereniging, sou mens nie anders kon as om daarop te wys dat die pers ook 'n bydrae gelewer het in die uiteindelıke mislukking van die kerkvereniging nie. Twee van die vernaamste redes waarom die kerkvereniging misluk het, was: 
Eerstens: omdat die gedagte van kerkvereniging nie sy ontstaan op kerlike vlak gehad he nie, maar op die nasionaal-politieke vlak. Hier het die pers ' $n$ baie belangrike rol gespeel om die volk emosioneel op te sweep om die politiek-staatkundige eenheid wat bereik is na die Vryheidsoorlog, te laat oorspoel na die kerklike erf.

Tweedens: die feit dat die poging tot kerkvereniging nie begelei is deur'n diepgaande teologiese debat waarin die gemeenskaplikhede en die verskille tussen die deelnemende kerke geanaliseer is nie. Die rol van die pers was ook hier belangrik, aangesien die standpunte van die Nederduits Gereformeerde Kerk beklemtoon is bo dié van die Nederduitsch Hervormde Kerk, waarvan soms nie eens melding gemaak is nie. Dit het ' $n$ besondere klimaat vir kerkvereniging geskep en daarby die kerkverenigingspoging eerder na 'n oorname van die Nederduitsch Hervormde Kerk laat lyk.

\section{Literatuurverwysings}

BOTHA, SJ 1966. Klerksdorp 1866-1966. Krugersdorp: NHW-Pers.

DE AFRIKAANSE PATRIOT 26 Augustus 1881 - Vergadering te Potchefstroom; 2 September 1881 - Die toekoms van Transvaal, IV. Hereniging van die Kerke; 28 Oktober 1881 - Die toekoms van Transvaal (Slot).

DE COLESBERGER 1884.

DE EENDRACHT 1885-1886.

DE GRAAF-REINETSCHE COURANّ̂T 1884.

DE OUDSHOORN COURANT 1881 en 1884

DE VOLKSTEM 23 November 1881 - Notule van die Algemene Kerkvergadering van die Nederduits Gereformeerde Kerk; 7 November 1881; 2 Desember 1881 - Het volksfees op Paardekraal; November 1882 - 31 Oktober 1882; 22 Januarie 1884; 29 April 1884; 13 Mei 1884; 5 Februarie 1885; 17 Desember 1885 - Algemene Kerkvergadering.

DE ZUID-AFRIKAAN 18 Julie 1877; 9 Augustus 1881; Het kerkelijke in de Transvaal; 26 November 1882 - Kerkvereeniging in de Transvaal; 28 November 1882 - Kerkvereeniging in de Transvaal; 14 Februarie 1885; Kerkvereeniging in de Transvaal.

DU TOIT, FGM 1979. HL Neethling: Sy lewe en werk. Pretoria: NG KERKBOEKHANDEL.

GERDENER, GBA 1930. Boustowwe vir die geskiedenis van die Nederduits Gereformeerde Kerk in die Transgariep. Kaapstad.

HET VOLKSBLAD 12 Februarie 1885.

KEET, DJ 1942. Wonderdade van God. Johannesburg.

KOTZE, DJ 1969. Nasionalisme, I: Van nasionalisme as historiese faktor. Kaapstad

PONT, AD 1978. Kerkgeskiedenis. Pretoria/Kaapstad: HAUM.

PONT, AD 1955. Nicolaas Jacobus van Warmelo 1835-1892. Utrecht.

PONT, AD 1965. Die Nederduitsch Hervormde Gemeente Waterberg 1865-1965. Krugersdorp: NHW-Pers.

NOTULE VAN DIE AGTSTE ALGEMENE KERKVERGADERING VAN DIE NEDERDUITS GEREFORMEERDE KERK 4 Junie 1877.

NOTULE VAN DIE KERKRAADSVERGADERING VAN MARICO 5 Mei 1877.

NOTULE VAN DIE ALGEMENE KERKVERGADERING VAN DIE NEDERDUITSCH HERVORMDE KERK 28 November 1881. 
NOTULE VAN DIE KOMMISSIE VAN DIE ALGEMENE KERKVERGADERING VAN DIE NEDERDUITSCH HERVORMDE KERK IN DIE SUID-AFRIKAANSE REPUBLIEK 8 Mei 1882.

NOTULE VAN DIE SITTING VAN DIE VERENIGDE KOMMISSIES VAN DIE NEDERDUITSCH HERVORMDE EN NEDERDUITS GEREFORMEERDE KERKE IN DIE SUID-AFRIKAANSE REPUBLIEK IN SAKE KERVERENIGING 31 Oktober 1882.

NOTULE VAN DIE ALGEMENE KERKVERGADERING VAN DIE NEDERDUITSCH HERVORMDE KERK IN DIE SUID-AFRIKAANSE REPUBLIEK November 1882.

VAN DER WATT, PB 1980. Die Nederduitse Gereformeerde Kerk 1824-1905.

VAN JAARSVELD, FA 1959. Die Ontwaking van die Afrikaanse nasionale bewussyn 1868-1881. Johannesburg. 